\title{
Physiological, Biochemical and Morphological Characteristics of Mesquite Wood-digesting Bacteria
}

\author{
By D. W. THAYER AND JAMES O. MURRAY* \\ Department of Biological Sciences, Texas Tech University, \\ Lubbock, Texas 79409, U.S.A. \\ (Received 15 November 1976; revised 3 January 1977)
}

\begin{abstract}
Ten species of bacteria, belonging to the genera Pseudomonas, Bacillus, Flavobacterium and Brevibacterium, were isolated from soil or decaying mesquite wood by enrichment culture techniques using mesquite wood as the carbon and energy source. Eight of these species hydrolysed carboxymethylcellulose but none consistently hydrolysed filter paper strips in peptone $/ \mathrm{NaCl}$ broth. In general, they were proteolytic, non-fermentative in Hugh \& Leifson's medium, utilized Kreb's cycle intermediates as sources of carbon and possessed carboxymethylcellulase.
\end{abstract}

\section{INTRODUCTION}

Mesquite brush (genus Prosopis) infests over 50 million acres in the State of Texas. The density of the brush cover, coupled with its very large thorns, greatly reduces the value of the land for grazing cattle. Research in this laboratory demonstrated the suitability of mesquite wood as a carbon and energy source for the growth of selected bacteria to produce a feed supplement or, potentially, a complete cattle feed (Thayer et al., 1975; Chang \& Thayer, I975; Fu \& Thayer, I975; Thayer, 1976a). The bacteria used in these studies were isolated from termites (Thayer, $1976 b$ ) and by enrichment culture techniques from soil and decaying wood. This paper describes the physiological and morphological properties of the strains of bacteria isolated by enrichment culture techniques from soil or decaying mesquite wood.

\section{METHODS}

Several species of bacteria were isolated by enrichment culture techniques. The basal medium, $\mathrm{pH} 6 \cdot 45$, contained $\left(\mathrm{g} \mathrm{I}^{-1}\right): \mathrm{NaCl}, 6 \cdot 0 ;\left(\mathrm{NH}_{4}\right)_{2} \mathrm{SO}_{4}, \mathrm{I} \cdot 0 ; \mathrm{KH}_{2} \mathrm{PO}_{4}, \mathrm{I} \cdot 0 ; \mathrm{K}_{2} \mathrm{HPO}_{4}, \mathrm{I} \cdot 0 ; \mathrm{MgSO}_{4} \cdot 7 \mathrm{H}_{2} \mathrm{O}, 0 \cdot \mathrm{I} 0 ; \mathrm{CaCl}_{2}, 0 \cdot 0 \mathrm{I}$; Difco yeast extract, 0.5 ; and mesquite wood (harvested while dormant in March and milled into sawdust), 10.0. Inocula (10.0 g) for enrichment cultures, obtained from decaying mesquite wood or the soil below it, were added to $100 \mathrm{ml}$ medium in $500 \mathrm{ml}$ baffled Erlenmeyer flasks. Cultures were incubated at $30{ }^{\circ} \mathrm{C}$ and agitated at $250 \mathrm{rev} . \mathrm{min}^{-1}$ for 3 days. Each third day thereafter, $10 \mathrm{ml}$ was removed to inoculate a sterile flask of mesquite medium for 10 successive transfers. From several such enrichment cultures, 65 isolates were obtained which grew well in the mineral salts medium containing mesquite wood as the major carbon source. Ten isolates were selected for further study because of their superior growth (as measured by viable cell number, bacterial proteins and substrate hydrolysis) on mesquite wood.

The morphological, cultural, biochemical and physiological characteristics were determined in duplicate by procedures described previously (Thayer, $1976 \mathrm{~b}$ ). Uninoculated and/or negative controls were included where appropriate. Flagellar morphology was confirmed by examining specimens, negatively stained with $2 \%(\mathrm{w} / \mathrm{v})$ phosphotungstic acid, in an Hitachi HS-8-2 electron microscope.

\section{RESULTS}

The morphological, biochemical and physiological characters of the 10 strains are given in Tables I to 5 .

* Present address: Academy of Health Sciences, Fort Sam Houston, San Antonio, Texas 78234, U.S.A. 
Table I. Morphological and biochemical properties of wood-digesting bacteria

Character

Cell morphology

Gram reaction

Endospores

Motility

Metachromatic granules

Growth

In TSB $+5.0 \%(w / v) \mathrm{NaCl}$

In TSB $+7.0 \%(\mathrm{w} / \mathrm{v}) \mathrm{NaCl}$

In TSB $+10.0 \%(w / v) \mathrm{NaCl} \dagger$

In presence of $0.001 \%$ lysozymet

At pH 5.7 , at $30^{\circ} \mathrm{C}$

At $41.5{ }^{\circ} \mathrm{C}$ in TSB

At $40^{\circ} \mathrm{C}$ in TSB

On $\alpha$-cellulose agar

On CM-cellulose agar

On microcrystalline cellulose agar

On microcrystalline cellulose agar + yeast extract

On BBL Pseudosel agar

Gelatin hydrolysis

Casein hydrolysis

Urea hydrolysis

Tryptophan hydrolysis

Lipid hydrolysis

Lecithin hydrolysis

Amylose hydrolysis

Pectin hydrolysis

CM-cellulose gel hydrolysis

DNA hydrolysis

Filter paper breakage

Methyl red test

Acetoin production

Catalase

Cytochrome oxidase

Peroxidase

L-Arginine decarboxylase

Nitrate reduction

Tyrosine decomposition

Dihydroxyacetone production

L-Arginine dihydrolase
Anaerobic in Brewer's thioglycollate

Biochemical tests

$\begin{array}{rcrccccccc}\text { JM } & \text { JM } & \text { JM } & \text { JM } & \text { JM } & \text { JM } & \text { JM } & \text { JM } & \text { JM } & \text { JM } \\ 127 & 92 & \text { I06 } & 99 A & 99 B & 98 A & 66 C & 68 B & \text { II6 } & 90\end{array}$

$\begin{array}{llllllllll}- & - & - & + & + & + & + & + & + & + \\ - & - & - & - & - & - & - & + & + & + \\ + & - & - & - & - & - & - & - & + & - \\ - & \text { NT } & - & - & - & - & - & - & - & +\end{array}$

$+\quad+-+++++$

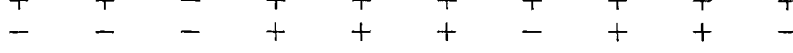

$-\quad-\quad-\quad-\quad-\quad-\quad-\quad-\quad+$

$+\quad+\quad-\quad-\quad-\quad-\quad+-$

$\begin{array}{llllllll} \pm & + & - & - & - & - & - & -\end{array}$

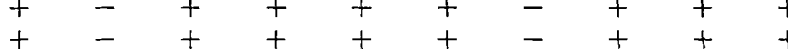

$+\mathrm{NT}++\mathrm{NT}++\mathrm{NT}$ NT

$\pm \mathrm{NT}+ \pm \mathrm{NT} \pm \pm \pm$ NT NT

$\pm++ \pm- \pm+ \pm+$

$+\quad \pm+\quad+\quad+\quad+\quad+$

$\begin{array}{llllllllll}+ & + & + & - & + & + & + & + & + & + \\ + & - & - & - & - & - & - & - & - & -\end{array}$

$\begin{array}{llllllllll}- & - & + & + & + & + & + & + & - & + \\ - & - & - & + & + & + & + & + & - & + \\ - & - & + & - & - & - & - & - & - & - \\ - & - & - & \pm & - & \pm & - & - & - & + \\ - & + & + & - & - & - & + & - & - & - \\ - & - & - & - & - & - & - & + & - & - \\ * & - & * & + & * & + & * & * & + & * \\ - & - & - & - & - & - & - & - & + & - \\ - & + & + & + & + & + & + & - & + & + \\ - & - & \text { NT } & - & - & - & + & - & + & - \\ - & - & - & - & - & - & - & - & 1 / 6 & 1 / 6 \\ - & - & - & - & - & - & - & + & - & - \\ - & - & + & - & - & - & - & + & - & - \\ + & + & + & + & + & + & + & + & - & + \\ + & + & + & - & - & + & + & + & + & - \\ + & + & + & - & - & + & + & + & + & - \\ + & - & - & - & - & - & - & - & - & - \\ \pm & - & - & - & - & - & - & + & + & + \\ + & + & - & \pm & \pm & + & + & \pm & - & \pm \\ - & - & - & - & - & - & - & - & + & - \\ + & \pm & \pm & \pm & \pm & - & - & - & - & +\end{array}$

+ , Positive; - , negative; \pm , doubtful; NT, not tested; $1 / 6$, one of six tests positive.

* Weak positive reaction below growth.

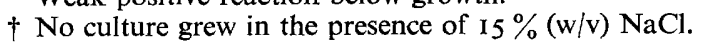

$\$$ Gordon, Haynes \& Pang (1973).

None of the organisms grew in $\mathrm{KCN}$ broth. All gave negative results in tests for phenylalanine deaminase, L-lysine decarboxylase, L-ornithine decarboxylase, and pigment production in the presence of $0.01 \%$ tyrosine. The Bacillus species $\mathrm{sM} 68 \mathrm{~B}$, JMI I6, and JM9o failed to grow at either $\mathrm{pH} 7$ or $\mathrm{pH} 6$ at $60^{\circ} \mathrm{C}$; the remaining strains were not tested for this property.

Strain JMI27 was identified as a species of the genus Pseudomonas. The differentiating characteristics of this organism were: unicellular, non-photosynthetic, non-sporeforming Gram-negative rod-shaped cells, 0.50 to $0.5 \mathrm{I} \times 0.85$ to $2.15 \mu \mathrm{m}$, occurring singly, motile with monotrichous or multitrichous polar flagella, chemo-organotrophs, oxidative by the Hugh \& Leifson (I953) method. Neither vitamins nor amino acids were required for growth. It may be related to Pseudomonas caryophylli based on the description of Doudoroff \& 
Table 2. Acid formation from carbohydrates

Carbohydrate

$\begin{array}{llllllllll}\text { JM } & \text { JM } & \text { JM } & \text { JM } & \text { JM } & \text { JM } & \text { JM } & \text { JM } & \text { JM } & \text { JM } \\ \text { I27 } & 92 & \text { I06 } & 99 A & 99 B & 98 A & 66 C & 68 B & \text { II } 6 & 90\end{array}$

Bromothymol blue broth base

Monosaccharides

D-Fructose

D-Galactose

D-Glucose

D-Mannose

Rhamnose

Disaccharides

$\beta$-D-Cellobiose

Lactose

Maltose

Melibiose

Sucrose

Trehalose

Polysaccharides

Inulin

Melezitose

Alcohols

Glycerol

Mannitol

Glucosides

Aesculin

Salicin

Hugh \& Leifson (I953) media

Glucose, aerobic

Glucose, anaerobic

$\begin{array}{llllllllll}- & - & \pm & + & + & + & - & + & + & + \\ + & + & - & - & - & - & - & - & - & - \\ + & + & + & + & + & + & - & + & + & + \\ + & + & + & + & - & + & - & - & + & - \\ - & - & - & + & + & + & - & - & - & - \\ & & & & & & & & & \\ - & - & + & - & + & + & + & - & + & - \\ - & - & - & - & - & - & - & - & - & + \\ - & - & + & + & + & + & + & + & - & + \\ - & - & - & + & - & + & - & - & - & - \\ - & - & - & + & - & + & - & + & + & + \\ - & - & - & - & - & - & - & + & + & -\end{array}$

Gordon media

Glucose slants

Glucose stabs

-, Acid not produced; + , acid produced; \pm , slightly acid; NG, no growth.

None of the organisms formed acid from L-arabinose, D-xylose, $\alpha$-amylose, raffinose, adonitol, dulcitol, inositol or sorbitol in bromothymol blue broth base. Strains JM I27, JM106, JM98A and JM66C did not produce acid aerobically and did not grow anaerobically in phenol red broth or Hugh \& Leifson media containing sucrose or lactose. Strain JM92 produced acid from glucose in phenol red broth, but not in any of the Hugh \& Leifson media. Strain JMIO6 did not produce acid aerobically from glucose in phenol red broth and failed to grow anaerobically in the same medium. Strain JM90 produced acid from xylose on Gordon's medium; strains JM68в and JMI 16 did not.

Palleroni (1974). At variance with this identification is its inability to reduce nitrate. After 5 days incubation on Difco Tryptic Soy Agar (TSA), colonies of JMI 27 were circular, convex, cream to tan, slightly translucent, $3 \mathrm{~mm}$ diam., had an entire margin, and did not produce soluble pigment. Abundant growth occurred on BBL Pseudosel agar (King, Ward \& Raney, 1954); after 4 days incubation the colonies were light tan, small ( $2 \mathrm{~mm}$ diam.), convex or umbonate, and did not produce soluble pigment. On Difco Pseudomonas $\mathbf{P}$ agar, colonies were round, translucent, light tan, about $3 \mathrm{~mm}$ diam., with an entire margin and a convex elevation; no soluble pigment was produced. On Difco Pseudomonas F agar, a water-soluble light-green fluorescent pigment was produced. The colonies were round with one concentric ring, an entire margin and umbonate elevation; they were $2 \mathrm{~mm}$ diam., light tan and had a slightly granular appearance. A pellicle was formed on liquid culture media. The most unusual characteristics of strain JMI 27 were its ability to rapidly degrade mesquite wood and to produce cellulolytic enzymes during growth (Thayer et al., I975; Thayer, $1976 c$ ). 
Table 3. Assimilation of organic acids from a modified Christensen medium (Yamada \& Komagata, 1972)

Acid

Pyruvic acid

Fumaric acid

$\alpha$-Ketoglutaric acid

Citric acid

Propionic acid

Butyric acid

Oxalic acid

Glutaric acid

Adipic acid

Pimelic acid

Glycollic acid

Hippuric acid

Uric acid

$\begin{array}{rrrrrrrrrr}\text { JM } & \text { JM } & \text { JM } & \text { JM } & \text { JM } & \text { JM } & \text { JM } & \text { JM } & \text { JM } & \text { JM } \\ \mathbf{I 2 7} & 92 & \text { I06 } & 99 A & 998 & 98 \mathrm{~A} & 66 \mathrm{C} & 68 \mathrm{~B} & \text { II6 } & 90 \\ + & + & - & + & + & + & + & + & + & + \\ + & + & + & + & + & + & \mathrm{NT} & + & + & + \\ + & + & - & + & + & + & \mathrm{NT} & + & + & + \\ + & + & + & + & + & + & - & + & + & + \\ + & + & + & + & + & + & - & + & - & \pm \\ + & + & - & + & + & + & \mathrm{NT} & + & - & + \\ + & - & + & + & + & + & + & + & + & + \\ + & + & - & - & - & - & \mathrm{NT} & - & - & + \\ + & + & - & + & + & + & \mathrm{NT} & - & - & + \\ - & - & - & - & - & - & \mathrm{NT} & - & - & + \\ - & - & - & - & - & - & \mathrm{NT} & - & - & - \\ + & + & + & + & + & + & \mathrm{NT} & + & + & + \\ + & - & - & + & + & + & \mathrm{NT} & - & - & -\end{array}$

,$+ \mathrm{pH}$ change from neutral to alkaline; -, no $\mathrm{pH}$ change; NT, not tested.

All strains used acetic, lactic, malic, succinic, formic and malonic acids.

Strain JM92 cells were short rods, $0.5 \times \mathrm{I} \cdot 0 \mu \mathrm{m}$, or cocci, $0.5 \mu \mathrm{m}$ diam., though some were lancet shaped. They were Gram-negative and non-motile. Colonies at $48 \mathrm{~h}$ and $35^{\circ} \mathrm{C}$ on standard agar media or TSA were round, with an entire margin and convex or drop-like elevation; they were 0.5 to $0.75 \mathrm{~mm}$ diam., smooth, glistening, translucent and yellow. Acid but no gas was produced from glucose. Lactose was not fermented. Strain JM92 was similar to Flavobacterium breve.

Strain JMIo6 was a small Gram-negative rod, $0 \cdot 8$ to $\mathrm{I} \cdot 0 \times \mathrm{I} \cdot 2$ to $2 \cdot 0 \mu \mathrm{m}$. Cells occurred singly and had round ends. Colonies on TSA were pale yellow, round, convex, opaque, glistening, smooth and I to $3 \mathrm{~mm}$ diam. Cultures in BBL Trypticase Soy Broth (TSB) became very turbid after $24 \mathrm{~h}$, but very little growth occurred in nutrient broth. This bacterium appeared to belong to the genus Flavobacterium but did not correspond with any species described in Bergey's Manual of Determinative Bacteriology (Buchanan \& Gibbons, I974).

Strain JM99A cells were Gram-positive rods, $0.6 \times \mathrm{I}$ to $2 \mu \mathrm{m}$, though some were curved. They did not have metachromatic granules. Colonies on TSA were light lemon yellow, raised, circular, I to $3 \mathrm{~mm}$ diam. and glistening. On cellulose agar, colonies were cream and spreading. There was no apparent clearing of the cellulose. Cells were non-motile and tended to be grouped in palisade arrangements. Cellulose strips were not hydrolysed in $0.5 \%$ peptone. Metabolism was oxidative but acid was produced from a number of carbohydrates. The same general description applied to JM98A and JM99B, although there were several differences between the individual strains. These three strains were placed in the genus Brevibacterium. The uncertain status of this genus prevented their speciation.

Strain JM66C formed colonies on TSA which were initially colourless, but later turned cream; they were flat with raised centres, smooth, umbonate, translucent, shiny and $\mathrm{I}$ to $\mathrm{I} .5 \mathrm{~mm}$ diam. after $24 \mathrm{~h}$. The cells were Gram-variable rods, $0.5 \times \mathrm{I}$ to $2.5 \mu \mathrm{m}$, though some were in palisade type groupings. This strain is apparently an unusual Brevibacterium species.

Strain JM68B had rod-shaped cells, 0.9 to $\mathrm{I} \cdot 0 \times \mathrm{I} \cdot 5$ to $3.5 \mu \mathrm{m}$, with flat to slightly concave ends. Endospores were formed. The sporangia were not swollen. Colonies on TSA were slightly irregular, beaded, erose-edged, off-white, opaque and dull-surfaced. A ring, turbidity and large amounts of off-white sediment were produced in TSB. Very poor growth occurred on Difco potato dextrose agar. The differentiating characteristics of this organism were: Gram-positive cells, ellipsoidal subterminal endospores that did not distend the 
Table 4. Assimilation of compounds as sole carbon source

\begin{tabular}{|c|c|c|c|c|c|c|c|c|}
\hline Compound & $\begin{array}{c}\text { JM } \\
127\end{array}$ & $\begin{array}{l}\text { JM } \\
92\end{array}$ & $\begin{array}{c}\mathrm{JM} \\
99 \mathrm{~A}\end{array}$ & $\begin{array}{c}\text { JM } \\
99 \mathrm{~B}\end{array}$ & $\begin{array}{c}\text { JM } \\
98 \mathrm{~A}\end{array}$ & $\begin{array}{c}\mathrm{JM} \\
68 \mathrm{~B}\end{array}$ & $\begin{array}{c}\text { JM } \\
\text { I I } 6\end{array}$ & $\begin{array}{l}\text { JM } \\
90\end{array}$ \\
\hline$\alpha$-D-Fucose & - & - & - & - & - & - & + & - \\
\hline Galactose & + & + & - & - & - & - & - & - \\
\hline D-Glucose & + & + & - & - & - & - & - & - \\
\hline Fructose & + & - & - & - & - & - & - & - \\
\hline Sucrose & - & - & - & - & - & - & + & - \\
\hline Xylose & + & + & - & - & - & - & - & - \\
\hline Acetic acid & + & + & + & - & - & - & - & - \\
\hline Adipic acid & - & + & - & - & - & - & - & - \\
\hline Benzoic acid & - & + & - & - & - & - & - & - \\
\hline Butyric acid & + & + & - & - & - & - & - & - \\
\hline Citric acid & + & + & + & + & + & - & + & - \\
\hline Formic acid & - & - & - & - & - & - & + & - \\
\hline Fumaric acid & + & + & + & + & + & - & + & - \\
\hline Hippuric acid & - & + & - & - & - & - & - & - \\
\hline$p$-Hydroxybenzoic acid & - & + & + & + & + & - & - & - \\
\hline DL- $\beta$-Hydroxybutyric acid & + & + & - & - & - & - & - & - \\
\hline 2-Keto-D-gluconic acid & + & - & + & + & + & \pm & - & - \\
\hline$\alpha$-Ketoglutaric acid & + & + & - & - & - & 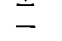 & - & - \\
\hline Lactic acid & + & + & - & - & - & - & + & - \\
\hline Malic acid & + & + & - & + & - & - & + & - \\
\hline Malonic acid & - & + & - & - & - & - & - & - \\
\hline Nononic acid & + & + & - & - & - & - & - & - \\
\hline Propionic acid & + & - & - & - & - & - & - & - \\
\hline Pyruvic acid & + & + & - & - & - & - & - & - \\
\hline Succinic acid & + & + & + & + & + & - & + & + \\
\hline Uric acid & + & - & - & + & + & - & - & - \\
\hline Butan-I-ol & - & + & - & - & - & - & - & - \\
\hline Ethanol & - & + & - & - & - & - & \pm & - \\
\hline Propan-I-ol & + & + & - & - & - & - & $=$ & - \\
\hline$\beta$-Alanine & + & + & - & - & - & + & - & - \\
\hline DL-Alanine & + & + & + & - & - & + & + & - \\
\hline$\gamma$-Aminobutyric acid & + & + & - & - & - & + & + & - \\
\hline DL-Arginine & + & - & + & + & + & + & + & + \\
\hline L-Aspartic acid & + & + & + & + & + & + & + & - \\
\hline Betaine. $\mathrm{HCl}$ & + & - & + & - & - & + & + & + \\
\hline L-Cysteine & - & - & - & - & - & + & - & - \\
\hline Glutamic acid & + & + & - & - & + & - & - & - \\
\hline L-Glutamine & + & + & + & + & - & + & + & - \\
\hline DL-Histidine & + & + & + & + & + & + & + & - \\
\hline DL-Isoleucine & \pm & - & - & - & - & - & - & - \\
\hline L-Isoleucine & $\overline{+}$ & - & - & - & - & + & - & - \\
\hline DL-Leucine & + & - & - & - & - & - & - & - \\
\hline L-Leucine & + & - & - & - & - & + & - & - \\
\hline DL-Methionine & + & - & - & - & - & - & - & - \\
\hline L-Phenylalanine & + & + & - & - & - & + & - & - \\
\hline L-Proline & + & + & + & + & + & - & + & - \\
\hline DL-Serine & + & - & - & - & + & + & - & - \\
\hline L-Serine & + & - & - & - & \pm & + & - & - \\
\hline DL-Threonine & - & - & - & - & - & + & - & - \\
\hline DL-Tryptophan & - & + & - & - & - & - & - & - \\
\hline L-Tyrosine & + & + & - & - & - & + & \pm & - \\
\hline
\end{tabular}

+ , Growth occurred on two consecutive transfers on the same medium; \pm , very small amount of growth; - , no growth.

None of the organisms grew without an added carbon source. Strains JMIO6 and JM66C did not grow on any compound tested singly. None of the organisms used glycollic, tartaric or oxalic acids, nor lactose, maltose, cellobiose, $\alpha$-cellulose, mannitol, glycine, L-valine, L-cystine, DL-norleucine, methanol or propan-2ol as sole carbon sources.

Strains JMI 27, JM99A, JM99B and JM98A required neither vitamins nor amino acids for growth though these substances greatly promoted growth. Strains JM92, JM68B, JMI I6, JM90 and JM66C required amino acids for growth. 
Table 5. Antibiotic sensitivity

Antibiotic

Bacitracin (Io u.)

Dihydrostreptomycin $(100 \mu \mathrm{g})$

Erythromycin $(50 \mu \mathrm{g})$

Erythromycin $(150 \mu \mathrm{g})$

Furadantin (1.5 mg)

Kanamycin $(100 \mu \mathrm{g})$

Nalidixic acid (100 $\mu \mathrm{g})$

Neomycin ( $100 \mu \mathrm{g}$ )

Penicillin G (5 u.)

Penicillin G (Io u.)

Streptomycin $(100 \mu \mathrm{g})$

Sulphathiazole $(3 \mathrm{mg})$

Tetracycline $(\mathrm{I} 00 \mu \mathrm{g})$

$\begin{array}{cccccccccc}\text { JM } & \text { JM } & \text { JM } & \text { JM } & \text { JM } & \text { JM } & \text { JM } & \text { JM } & \text { JM } & \text { JM } \\ \text { I27 } & 92 & 106 & 99 A & 99 \mathrm{~B} & 98 \mathrm{~A} & 66 \mathrm{C} & 68 \mathrm{~B} & \mathrm{II} 6 & 90 \\ - & \pm & \pm & + & + & + & + & \pm & - & ++ \\ ++ & ++ & - & ++ & ++ & ++ & ++ & + & + & ++ \\ - & + & + & ++ & + & + & ++ & ++ & ++ & ++ \\ - & ++ & ++ & ++ & + & ++ & ++ & ++ & ++ & ++ \\ - & - & + & - & - & - & - & ++ & ++ & ++ \\ ++ & ++ & - & + & + & + & ++ & + & ++ & + \\ - & - & ++ & \pm & - & - & - & \pm & ++ & - \\ + & + & + & ++ & + & \pm & ++ & + & + & ++ \\ - & - & - & - & \pm & + & + & + & ++ & + \\ - & - & - & + & + & + & ++ & + & ++ & + \\ + & ++ & - & ++ & + & + & ++ & + & + & ++ \\ - & - & - & ++ & ++ & ++ & \pm & \pm & + & \pm \\ \pm & - & + & ++ & ++ & ++ & ++ & ++ & + & ++\end{array}$

- , No zone of inhibition; \pm , small zone of inhibition; + , moderate zone of inhibition; ++ , large zone of inhibition.

sporangium, catalase positive, produced acid from glucose, produced acetoin but not gas. Strain JM68B was classified as a variety of Bacillus megaterium, most likely the subspecies Bacillus carotarum.

The differentiating characteristics of strain JMI 6 were: Gram-positive rod-shaped cells, 0.5 to $0.75 \times 2$ to $3 \mu \mathrm{m}$, ellipsoidal endospores in a central or subterminal position that did not distend the sporangium. Colonies on TSA were irregular, about 3 to $10 \mathrm{~mm}$ diam. after 5 days incubation, umbonate, with wrinkled surfaces, lobate-edged, white and opaque. A pellicle and flocculent sediment were produced in TSB. There was abundant, white growth on potato dextrose agar. The organism required one or more amino acids for growth. It hydrolysed carboxymethylcellulose gels very rapidly. Strain JMII6 may be related to Bacillus pulvifaciens.

Strain JM9o had large $(\mathrm{I} \cdot 0$ to $\mathrm{I} \cdot 5 \times 3 \mu \mathrm{m})$ Gram-positive rod-shaped cells with cylindrical and subterminal endospores; the cells stained poorly with the Gram stain and appeared foamy. Colonies at $24 \mathrm{~h}$ on TSA were $\mathrm{I} .5$ to $3.0 \mathrm{~mm}$ diam., mucoid, shiny, convex and off-white. Seven-day-old colonies on TSA were I to $3 \mathrm{~mm}$ diam., smooth, raised, entire-edged, opaque, dull and off-white. Strain JM9o was catalase positive and may be related to B. pulvifaciens.

\section{DISCUSSION}

All the strains described here were isolated by enrichment culture techniques with ground mesquite wood as the source of carbon. These io strains were selected for further study on the basis of their ability to grow rapidly on the wood. Thus all were presumed to have some ability to degrade and utilize the components of wood. All strains were isolated from soil and/or decaying wood though none are phytopathogens. None could weaken filter paper sufficiently for it to break during every test. However, all but two strains hydrolysed carboxymethylcellulose gels. Of the strains tested, all except JM99в grew on $\alpha$-cellulose, carboxymethylcellulose or microcrystalline cellulose agars. Other activities which might be associated with wood degradation such as amylose hydrolysis, pectin hydrolysis and utilization of xylose were not common.

Some cellulolytic activities of these strains have been described previously, and presumptive evidence was found for the degradation of lignin by JMI27, JM68B, and JM99A (Thayer et al., I975). In a later report, Thayer (I976c) questioned the validity of the cellulose strip hydrolysis test and tentatively proposed that strains JM98A, JM99A and JM99B were non-typical Cellulomonas strains. However, Braden \& Thayer (I976) found the cell wall antigens from 
JM98A and JM99A had a low serological cross-reaction with any of six authentic Cellulomonas species and concluded that they were not members of that genus.

The majority of the Io isolates utilized citrate, fumarate, succinate, alanine, arginine, aspartic acid, glutamine, histidine and proline. Most could assimilate more compounds than could be used as sole sources of carbon. Thus they tended to be proteolytic, oxidative and capable of utilizing Kreb's cycle intermediates as sole sources of carbon.

We thank Susan Claire Robinson for her technical assistance. This investigation was supported by funds from the Brush Control and Range Improvement Association, The Dodge Jones Foundation, and the State of Texas.

\section{REFERENCES}

Braden, A. R. \& Thayer, D. W. (1976). Serological study of Cellulomonas. International Journal of Systematic Bacteriology 26, I 23-I 26.

Buchanan, R. E. \& GibBons, N. E. (editors) (1974). Bergey's Manual of Determinative Bacteriology, 8th edn. Baltimore: Williams \& Wilkins.

Chang, W. T. H. \& Thayer, D. W. (1975). The growth of Cytophaga on mesquite. Developments in Industrial Microbiology 16, 456-464.

DoudorofF, M. \& Palleroni, N. J. (1974). Genus I. Pseudomonas Migula I894. In Bergey's Manual of Determinative Bacteriology, 8th edn. p. 217. Edited by R. E. Buchanan and N. E. Gibbons. Baltimore: Williams \& Wilkins.

Fu, T. T. \& Thayer, D. W. (I975). Comparison of batch and semicontinuous cultures for production of protein from mesquite wood by Brevibacterium sp. JM98A. Biotechnology and Bioengineering 17, I $749-1760$.

Gordon, R. E., Haynes, W. C. \& Pang, G. H-N. (1973). The Genus Bacillus. Agricultural handbook no. 427. Washington, D.C.: Agricultural Research Services, United States Department of Agriculture.

Hugh, R. \& Leifson, E. (1953). The taxonomic significance of fermentative versus oxidative metabolism of carbohydrates by various Gramnegative bacteria. Journal of Bacteriology 66, 2426.
KING, E. O., Ward, M. K., \& Raney, D. E. (I954). Two simple media for the demonstration of pyocyanin and fluorescin. Journal of Laboratory Clinical Medicine 44, 30I.

THAYER, D. W. (I976a). A submerged culture process for production of cattle feed from mesquite wood. Developments in Industrial Microbiology 17, 79-89.

THAYER, D. W. $(1976 b)$. Facultative wood-digesting bacteria from the hind-gut of the termite Reticulitermes hesperus. Journal of General Microbiology 95, 287-296.

THAYER, D. W. (1976c). Cellulolytic and physiological activities of bacteria during production of single-cell protein from wood. In Proceedings of the American Institute of Chemical Engineers Eighty-First National Meeting p. 44, paper no. I $7 \mathrm{~b}$.

Thayer, D. W., YANG, S. P., Key, A. B., YANG, H. H. \& BARKer, J. W. (1975). Production of cattle feed by the growth of bacteria on mesquite wood. Developments in Industrial Microbiology 16, 465-474.

Yamada, K. \& Komagata, K. (I972). Taxonomic studies on coryneform bacteria, IV. Morphological, cultural, biochemical and physiological characteristics. Journal of General and Applied Microbiology 18, 399-4I6. 